\title{
International/Cooperative Frameworks for Remedying the Safety Issues Present in Immigration Management
}

\section{NAGYNÉ CSOBOLYÓ Eszter}

\begin{abstract}
Today we can declare, that the question of migration and safety/security belong together. The creation and/or upkeep of safety is a public duty, on which civil and law enforcement, national and international agencies need to take action, working together as a group. The aim of this article is to show the international cooperation.
\end{abstract}

Keywords: migration, safety/security, cooperation, civil and law enforcement, police, army

In 2015, at the beginning of my doctoral studies, the issue of immigration became an important topic in politics and public discussion - not just at home, but all over Europe. The motive behind my research is based in an inherited tradition that, beyond spiritual, theological, or, simply, primary religious practices, social responsibility is a crucial element of the reformed theology. God and the present love found in God's Son, Jesus Christ, should not stay within the boundaries of the church, nor within temporary boundaries intended for defense. God is the Lord of all and thus, there is nothing that exists in time or space, nor within the physical realm or the spiritual realm that does not belong to Him.

The topic of my doctoral studies focuses on immigration related activities of non-governmental organizations, with a particular focus on the collaboration with law enforcement. The goal of my research is to examine the management of immigration today - at home, as well as internationally - mainly from the perspective of nongovernmental organizations. What can the Church do? How can civil and/or non-profit organizations take action regarding immigration?

The evaluation of the last three years is painful, easy to summarize. In the handling of immigration issues, we have gone from a just and humanitarian outreach to a kind of situation in which even hearing about civil organizations makes our hearts ache, stomachs hurt, and even - in the event of monetary support - our wallets empty. Perhaps specific events come to mind, such as the Italian prosecution ${ }^{1}$ of civil organizations,

According to Italy's Prosecution Office's date, in 2016, these organizations saved and transported to Italy 70 thousand out of more than 181 thousand people, who had arrived to Italy's shores. 
or the domestic legislative amendment ${ }^{2}$ brought about by the sector's financial transparency, as well as Strasbourg's ruling on the Bangladeshis. ${ }^{3}$ We, Hungarians have become "richer", so to speak, in terms of negative experiences and new words that did not exist in our language until today, such as immigrant pettler, immigrant business, and welcome politics, etc. During all of this, at the beginning of 2017, 600 people had to be extradited from the Belgrade jungle alone due to the demolition of the warehouses functioning as temporary accommodations. During this time, more than 5,000 requests for residency were registered ${ }^{4}$ and the regions affected by the refugee crisis, for example the populated Middle Eastern region is a place for religious prosecution, as well.

According to early 2018 British internal sources, there are 56,000 foreigners who have fled their countries, for whom current places of residence are not known by the British authorities; at the same time, Germany cannot find 30,000 rejected asylum seekers. Meanwhile, in Denmark, the number of immigrants are uncontainable. The arrival of those deemed to be threats to security is ongoing, despite the efforts made towards route closures in the Balkans. In 2017, more than 150,000 immigrants arrived in Europe via the Mediterranean Sea: 113,000 in Italy, 24,000 in Greece, and 18,000 in Spain. ${ }^{5}$

According to NATO, the influx of immigrants is not decreasing. Analysis of the situation shows that from northern Africa and the Sub-Saharan African regions alone, which do not include Pakistan or Afghanistan, 60 million people will have left their homes by 2020. The potential incoming crowds from Africa are unlimited. According to projections, the continent's population is expected to double in the coming period of time, exceeding the current 2 billion, which will result in serious economic difficulties for several African countries. The reasons for immigration are demographic and water management problems, as well as unstable political environments. NATO's projection coincides with Frontex's and the United Nations High Commissioner for Refugees' projections, as well. According to Frontex, 34-36 million people have already left their homes, bound for Europe. On Libia's shores, 1 million people are currently waiting for boats, while more than 1.5 million people from the Horn of Africa would like to leave, as well. Additionally, 3.6 million people are still being held in Turkey by the Turkey-EU Refugee deal. ${ }^{6}$

\footnotetext{
Organizations that actively support immigration without question participate in foreign finance. The Fidesz-fraction presented the proposal purposed for the creation of transparency and the government supported it. The FARA (Foreign Agents Registration Act) law provides the foundation of this law, the Hungarian regulations, however, in many ways, are less than the American regulations. The point of the law proposal, in case of foreign support - about a certain amount - is that organizations must make public the following facts: who are the supporters, what kind of support and whom are they receiving it from.

3 The Strasbourg Civil Rights Court announced a sentence in the Ilias and Ahmed v. Hungary case. They held the 2 Bangladeshi citizens for 23 days in a transit zone on the Hungarian border and later transported them to Serbia. On March 14, 2017, the court stated that this offended the European Human Rights Treaty, Article 5, para. 1 and 4 which concerns freedom and safety rights - the Röszke accommodations deprived them of their freedom, in that they could have made a formal decision, and they could have assured a possibility of a sufficient legal remedy.

$4 \quad$ Immigration and Asylum Office, 15.05.2017.

$5 \quad 08.11 .2017$.

$6 \quad 28.09 .2017$.
} 
The current situation is unusually serious. In this current situation, however, no one can say with a clear conscience that they do not need to concern themselves with immigration because it affects us all. The fulfilment of the humanitarian mission applies to all of us and to many of us the fulfilment of the Christian mission applies as well, according to which we must care for the matters of our communities and the world. The task of the preservation of justice, peace, and creation includes, without question, immigration issues.

\section{Domestic Regulations}

One of the domestic regulatory basis of the immigration issue is Directive 1035/2012. (II. 21.) on Hungary's National Security Strategy. The III. part of the Strategy deals with the threats and challenges affecting Hungary and the respective handling of these issues. In this section, the issues of immigration also received attention. The presence of immigration contains complex economic and demographic advantages and equally many risks regarding national and international security. Our commitment to the union comes with the responsibilities and duties of administration of the border sections, we handle the redress of security questions regarding the management of illegal immigration issues in international and/or cooperative frameworks, which are as follows:

- increased protection of external borders

- action against illegal immigration

- management of organized crime

- development of politics directed at deportation, homecoming and readmission

- the filtering of individuals who pose national security threats

- regulation of entry and residence permit granting procedures

- integrated border management

The endeavour towards the creation and maintenance of security has been expanded to a public interest in the European Union. The policy for more efficient operation and fiscal savings requires that union and domestic law enforcement agencies take action together in one system. According to the summation of the date at the end of 2017, there were 9,000 acts of terror committed, while in the collective 27 terror attacks, more than 330 lost their lives and 1,300 were wounded. ${ }^{7}$ According to the press conference of the Ministry of the Interior held on March 23, 2018, Hungary has become the world's $15^{\text {th }}$ safest country.

Starting on January 1, 2008, from the integration of the Border Patrol, the Hungarian Police administers the protection of external borders. ${ }^{8}$ Following our joining the European Union on May 1, 2004 and the Schengen states on December 21, 2007,

\footnotetext{
Napi kommunikáció, 08.11.2017.

8 The Fundamental Law of Hungary, Article 46, Para. 1.
} 
the monitoring of all traffic crossing the borders (except the air) into Austria, Slovenia, and Slovakia ended. As far as our "neighbours" are concerned, Slovakia, Austria, and Slovenia are privileged to full rights as partner countries; Romania and Croatia are allies in the Union, but not full members of the Schengen states; and Serbia and Ukraine are not members of the Union. The total length of Hungary's border is 2,242.603 km, which creates in itself 7 borders with 7 other countries. Of this, $1,103.528 \mathrm{~km}$ is the length of the Schengen outer border. The protection, guarding, and monitoring of the outer borders is a responsibility that burdens the member states.

The monitoring of the Hungarian border section is administered by the Border Police Authority, which is incorporated by the police organization. While all the duties of the border patrol are being performed, this Authority, which was created to oversee general police duties, assures the protection of the border, the monitoring of border-crossing traffic, as well as all jobs pertaining to the maintenance and upkeep of the border. This authority also fulfils all illegal immigration management related law enforcement duties, as well as those related to the upkeep of the border. In the interest of the performance of these duties, patrol and passport officers follow official procedures.

\section{Headquarters of the Border Police Authority}

\begin{tabular}{|c|c|}
\hline 1. & Bács-Kiskun county \\
\hline 1.1. & Hercegszántó \\
\hline 1.2. & Bácsbokod \\
\hline 1.3. & Bácsalmás \\
\hline 1.4. & Kelebia \\
\hline
\end{tabular}

\begin{tabular}{|c|c|}
\hline 2. & Békés county \\
\hline 2.1. & Battonya \\
\hline 2.2. & Lőkösháza \\
\hline 2.3. & Gyula \\
\hline 2.4. & Kötegyán \\
\hline 2.5. & Biharugra \\
\hline
\end{tabular}

\begin{tabular}{|c|c|}
\hline 3. & Csongrád county \\
\hline 3.1. & Szeged \\
\hline 3.2. & Kiszombor \\
\hline 3.3. & Nagylak \\
\hline
\end{tabular}

\begin{tabular}{|c|c|}
\hline 4. & Hajdú-Bihar county \\
\hline 4.1. & Biharkeresztes \\
\hline 4.2. & Létavértes \\
\hline 4.3. & Nyírábrány \\
\hline
\end{tabular}




\begin{tabular}{|c|c|}
\hline 5. & Szabolcs-Szatmár-Bereg county \\
\hline 5.1. & Nyírbátor \\
\hline 5.2. & Csenger \\
\hline 5.3. & Kölcse \\
\hline 5.4. & Beregsurány \\
\hline 5.5. & Barabás \\
\hline 5.6. & Záhony \\
\hline
\end{tabular}

\section{Domestic Collaborations}

\section{In the Police Department}

\section{Border guard}

An elaborate example of the civil sector's group performance is that the Hungarian Government decided in August of 2016 to reinforce the border guard due to the growing pressure of illegal immigration and on the basis of the reports of secret agencies, a decrease in illegal immigration was not expected. In addition to this, the workload of the police force needed to be reduced, and the balanced national security situation needed to be maintained. It was also important to ensure that the population's sense of security would not dissolve.

Following the decision to expand the police reserves by 3,000 people, the police guard recruitment began, which, as a result, lead to 574 people beginning their studies on November 2, 2016. Following the completion of the first module of training, 532 people successfully completed the exam, who then continued their studies as provisional officers following being sworn in on January 12, 2017, after the successful completion of the final exam, which took place in April. Beginning on 2 May, 514 new police officers were ready for service. Police officers, who were only partially qualified for duty as guards or patrol guards in the Police Reserves staff of the Deployment Office may only perform guard or guard patrol duties under the instruction of the sergeant. In different locations throughout the country - including 04.10 Somogy, Sümeg and surrounding areas, Vas county, etc. - the police continue to hold recruitments for the training of border guards.

\section{Out of the Police Department}

\section{Civil organizations}

From the sector of civil organizations, in order to reinforce or strengthen active civil associations in the border areas in Csongrád and Bács-Kiskun counties, it is important to highlight the July 21, 2016 dated National Civil Watch Alliance plan of action. According 
to the content of the plan's preamble, at the request of Dr. Sándor Pintér, all civil watch associations in the towns within the 8 kilometre wide border lane should participate in the guarding of the border. Among the many duties, the plan has prescribed collaboration between the police department and the civil guard for areas within 8 kilometres of the border, concentrating mainly on patrol guards and watch keeping. In the deeper territories of the country, on behalf of the civil watch, collaboration focuses on watch keeping - the approximate number of immigrants, personal descriptions, direction of movement, and vehicle identification - and, following the detection of immigration, prompt signalling to the police department. In Csongrád county, 1,677 people are ready for service and in Bács-Kisun county, 3,397.

According to the plan of action, the Department of Civil Border Protection was created on January 21, 2017 as a result, whose goal was that the settlements along the border must help in the prevention of the violation of rights caused by immigrants, as well as the creation of more technical, more efficient, and more coordinated conditions for civil watch services. In the frameworks of a celebration, Dr. Norbert Rádi, Police Colonel, Head Political Advisor, and Chief of Police Headquarters' Criminal Department, said that the civil watch of Csongrád county helped considerably in the protection of the border and with the accounting of human trafficking with appropriate and reliable signalling, which has given him hope that, with the creation of this department, the cooperation among the two organizations will be even more efficient and productive.

\section{National Security Services}

The successful collaboration along the borders between the Police Department and the Hungarian Military Forces also confirms that during the September 21, 2015 assembly of Parliament, the 2015 CXLII law was accepted, which concerns the amendments of particular laws pertaining to the more efficient protection of the Hungarian borders and the handling of mass immigration. A necessary action of the past period that was taken, was the creation of duties and broadening of power of the Police Department and Hungarian Military Forces. According to the general justification for the law, the number of those illegally crossing the border increased drastically compared to the amount in 2014. The new government response to foreign mass immigration is the introduction of the "crisis caused by mass immigration" civil rights establishment, which necessitates the amendment of certain legislation provisions. ${ }^{9}$ At the beginning of March 2017, the Hungarian Government extended by a half a year the crisis caused by the validated mass immigration into the territory of the entire country. A decision was made about the maintenance of the crisis situation, which lasted until September 7, 2018, which was deemed necessary because 800,000 and some people have become stuck in the Balkan region, who are not able to return to Turkey. ${ }^{10}$

\footnotetext{
2007 LXXX law concerning refugee rights.

10 Inforadio, 15.05.2017.
} 
The 2015 CXLII law makes is possible for the 1994 XXXIV law, which concerns the Police Department, to materialize in accordance with the rules of the mass-immigration -caused crisis which concerns the rights of refugees. This has allowed the necessary amendment of the 2011 CXIII law related to national defence, the Hungarian Military Forces, and provisions of due process, as well as, the coordination of immigration -related regulations. In cooperation with the amending of the law concerning the Police Department, as well as with the police department and national safety services, and in the interest of the detection of actions which endanger the order at the borders, as well as in the interest of the execution of necessary provisions towards the management of mass migration, foreign exploratory activities may continue. The maintenance of special situations is most effective with a team - police, military, and national security services. As unfortunate experiences of the past have shown, the problem of terrorism cannot be separated from the issue of immigration. In the areas of mass immigration, the reality that certain groups and organizations want to utilize migration processes for illegal purposes, must be taken into consideration. Such unlawful initiatives posing a threat to the national security should result in a more assertive approach - in the field of the fight against terrorism - from the agencies with the competencies - such as the police - to counter these threats to have the above mentioned competences to be reviewed, and if needed, expanded. The purpose of the provision, the activities of those wishing to make profit off of illegal immigration, for example human traffickers, must be detected by the abilities and capabilities of the police without this secret collection of information being tracked by systems.

There is live, daily cooperation between the TEK (Counter Terrorism Centre) and national and international partner agencies. This close flow of information guarantees the safety of the country. The safety challenges regarding immigration belong to the Information Office and the Military National Security Service. On the basis of the 1995 CXXV law, the Information Office and Military National Security Service acquires, analyses, evaluates, and forwards information which originates from foreign countries and it is necessary for government decisions and usable in the interest of the nation's safety, and continues activities providing the validation of Hungarian interests. The National Security Service's Exploratory Administration completes activities related to collecting information. The Office of Constitutional Protection completes the monitoring of those who are requesting a settler's permit, requesting recognition as refugees, respectively those petitioning for citizenship, and those who have submitted requests for visas (regarding the protection of the order of the constitution and state sovereignty.) The office monitors all other duties related to this, as well. Within the framework of this activity, the office carries out all duties related to legal and illegal immigration, which contributes to the prevention of any terrorist or criminal who pose a threat to Hungary and/or any state of the European Union from entering the territory. 


\section{Military Forces of Hungary}

At the border, the Military Forces of Hungary help the Police Department in maintaining the order and this assistance brings justification to the amendments of the 2011 CXIII law. The Police Department and the Military Forces of Hungary began the implementation of the assignment named "Közös Akarat" ("Common Will") on September 22, 2015. In 2017, around 17,000 soldiers participated in the management of the illegal migration situation in protection of the southern borders with the help of other law enforcement agencies. ${ }^{11}$ The basic assignment of the Military Forces of Hungary is the protection of the independence, regional integrity, officially and internationally recognized borders, population, and material wealth of Hungary. ${ }^{12}$ The Military Forces participate in the defence and guarding of the state border in mass migration actions. It eliminates all forceful acts, which are directed against the order of the state border. In many situations their powers are similar to the rights of police officers: the examination of identification, production, clothing, vehicles, and packages, the search and seizure of intentional committers of crime and those illegally residing in the country; securing of the location; directing, restricting, and prevention of traffic; the application of coercive measures; and border patrol. The Military Forces can help the Police Department over the course of their assignments only in areas affected by the crisis situation caused by mass immigration. The military organizations execute additional assignments in an independent system under the direction of their own personal orders. According to the military law, during the course of the performance of additional assignments, a soldier may not be encumbered by the commitment of using a weapon. However, for the infliction of bodily wounds - rubber bullets, pyrotechnics, tear gas grenades, capturing nets - may be used.

Due to abnormal situations, the Parliament modified the 2012 CCV law pertaining to the legal status of privates. The law states that orders received to carry out additional assignments must be performed by a member of staff who has self-sacrificing courage and that all other related orders must be completed even if the staff member's life or well-being is directly or seriously in danger. Given this, actions signal the seriousness of the situation, as well as the fact that the complex handling of the issue can only be managed with this joint realization.

The joint refusal of the Minister of the Interior and the Minister of Defence of 25/2015 (IX.14.) BM-HM is about the order of the Hungarian Military Forces' contribution, which occurred during the execution of the police assignments. Mutual cooperation extends to the protection of Hungary's state border and the completion of assignments requiring special tools and military expertise, in the interest of defending the order of the border, as well as in the interest of supporting the carrying out of necessary police and military assignments. According to the content of the order, the Military

\footnotetext{
Napi kommunikáció, 06.12.2017.

122011 CXIII law about the national defence and Hungarian Military Forces, as actions were introducible in due process.
} 
Forces of Hungary provides food to those involved and the staff of the organizations participating in the execution of mass immigration related assignments. In the event that the police department's official group requests the military's present headman, or in his absence the soldier, to manage the action determined by the carrying out of common service assignments, the completion of the request may only be refused if the management of the action in question conflicts with the law, the requested soldier cannot be expected to complete the requested legal and professional management, or it is not possible given the current conditions. The police are in charge of the guard patrol. The police department must perform the guarding and/or defence of the transit zone with the independent and fully accredited supply provided by the Military Forces of Hungary. The Military Forces of Hungary serve the defense of the borders. In 2017 it created a mandate, according to which the number of reserve soldiers will increase by 1,000 members by the end of the year, ultimately reaching 6,000 members. According to the plans, the current existing number in the reserve will grow to 20,000 by 2026, adding to the currently existing 30,000 in the Military Forces of Hungary. According to the plans, in all 197 districts there will be some kind of territory protection unit, with which they will be able to detect more efficiently any suspicious activity or people. ${ }^{13}$ The volunteer reserve system strengthens the country's ability to defend itself against terrorism and illegal immigration. The goal is that Hungary's important basis should be in the recruitment of reserve soldiers and for this reason we are applying for NATO's reserve force and leadership, as well.

\section{International Cooperations}

\section{Institutional}

\section{Public Liaison Service Locations}

As a result of mass immigration, not only the civil sector and police department were transformed, but the relations between the countries, as well - in both situations: either that newer conflicts developed or international relations improved. The 2017 early-April government briefing confirms this. According to this, the Hungarian authority's relationship with their Roman partner agencies is outstanding, who readmitted every single person who had arrived illegally; the same cannot be said of Serbia. We must take into consideration that Serbia was not able to readmit arrivals from its country. On October 5, 2017, the V4s decisions were introduced, wherein it has been offered to the outer border partner states, that, should it be needed, they will participate in the protection of the outer border.

The international coordination institution's essential example is the Public Liaison Service Locations in its carrying out of the border traffic assignment, which greatly

13 Napi kommunikáció, 03.10.2017. 
contributes to the monitoring and international exchange of information. The basis for the creation of the Service Locations is the bilateral consensus among the countries, which, among many things, may come to fruition in the furtherance and enhancement of the cooperation of the beyond-borders-reaching police department and the information connected to the territory of the police department, in the coordination of the common monitoring and supervisory assignments and/or other acts within the mutual border, rather along the mutual borders of all parties; with the compliance of the valid treaties, the illegally incoming or residing, in all issues regarding the readmission of the citizens of the party members and third-world countries; in the exchange of information related to the prevention, restriction, and prosecution of criminal activity; in the coordination of all cooperative forms regarding the public actions against illegal immigration and subsequent unlawful acts. ${ }^{14}$

In 2005, the time came for the transaction of the agreement with Slovakia and the Public Liaison Service Locations, established along the border Rajka-Dunacsúny, Balassagyarmat-Szlovákgyarmat and Sátoraljaújhely-Szlovákújhely. ${ }^{15}$

From 2006 at the border of Ártánd-Bors.

In 2007, in the Hungarian-Austrian relationship a Service Location was created at Hegyeshalom-Nickelsdorf.

Since 2007, the Service Location on the Rédics-Hosszúfalu border works with Slovenia. ${ }^{16}$

From 2010, a Service Location operates at Kiszombor-Nagycsanád.

In 2013, an agreement was created by the Croatian parties for the operation of a Service Location.

Since 2014, a Service Location is operating with Serbia at Röszke.

Since January 1, 2017, the operation of the first Ukrainian Service Location began at the border crossing of Záhony-Csap on the Hungarian side of the border.

\section{Personal}

In the interest of the efficient carrying out of the assignments, in the recent past there were several examples for the international personal cooperation, in the frameworks of which police and soldiers in Hungary's territory, and/or Hungarian police and soldiers outside of Hungary completed service.

In the Fall of 2015, the Czech Republic sent law enforcement agencies to Hungary, so that they could be of some help in the accounts of problems caused by illegal immigration. The two other Visegrád countries - Poland and Slovakia - also represented themselves in the same year within our borders regarding the management of the refugee crisis.

\footnotetext{
Directive 274/2007. (X. 20.)

Directive 91/2005. (V.6.)

Directive 318/2007. (XI.23.)
} 
Policemen completed service in Slovenia in December of 2015. Working under Slovenian direction, they patrolled for the purpose of public order, the prevention of the violations of rights, as well as the defence of the outer borders of the Schengen territory in cooperation with the local police.

In March of 2017, a new police contingency started to Macedonia. This was the fourth unit that participated with 30 policemen in the mutual border management procedures of admitting countries, for example in the defence of the MacedonianGreek border. Through the end of 2017, Hungarian police units were continuously sent to Macedonia monthly. The performance of patrol service was the main duty of the Hungarian police in the interest of the prevention of unlawful border crossings and detection, and/or they assisted in the prevention of human traffickers and illegal immigrants crossing into Macedonia. From a safety perspective it is critically essential, that the Western-Balkan route remain closed. This is why the cooperation between Hungary and Macedonia is paramount.

In September of 2017 - COOPSEC 2017 - Hungarian, Austrian and Czech soldiers held public border defence exercises in Austria.

In March of 2018, Hungarian and Slovak soldiers continued the border defence exercises in the Kelebian section, in which they showed how the temporary safety border-lock works, the soldier and police tools utilized in assignments, as well as the Kelebian border defence base.

\section{Organizational}

On April 7, 2017, the new union regulation regarding border monitoring took effect, which prescribes systemic monitoring of all those entering or leaving the European Union and all Union or third-world country citizens. All travel documents must be compared and contrasted with the Schengen Information System, respectively the Interpol national police organizations database of lost or stolen travel documents, so that the authorities can be sure that the individual in question does not pose a threat to safety, public order, or public health in the EU. The resolution also mentions that it must be authorized that the union members need not perform systematic monitoring, if they can provide evidence that the refrain from monitoring would not cause safety threats. In this context, on May 9, 2017, the Hungarian Government temporarily suspended the application of the union regulation for systemic border monitoring in the context that, due to the action, there are long waits in several regions along the border, fearing that in the summer the waiting would become even longer. In place of the systematic border monitoring, targeted border monitoring was introduced. On November 8, 2017, the Government rescinded the introduction of the systematic border monitoring as a result of the government decision concerning the situation that developed within Hungary's borders.

The European Council accepted a decision on December 11, 2017 regarding the creation of Permanent Structured Cooperation (PESCO). The institution of the Permanent 
Structured Cooperation, which belongs to the territory of safety and defence politics, was introduced by the Lisbon Contract. PESCO created an opportunity for the singular union states to continue closer cooperation in the areas of safety and defence. This permanent defence cooperation framework will make it possible for those states willing and able to develop jointly/mutually their defence abilities, to invest in mutual projects, as well as improve the readiness and contribution of their armed forces.

The timetable was accepted on March 6 concerning the execution of PESCO and the Council, which ensured strategic direction for the structuring of further work. It determines furthermore the schedule of the national executional plans, additionally main elements of future projects, as well.

The EU and NATO group signed a declaration on July 8 regarding the tighter securing of their cooperation in seven strategic territories, which includes defence abilities, as well. At the end of 2017, the time came for the summit meeting of NATO's Ministers of Foreign Affairs, in which they determined that in the interest of the security of Europe, they can stop the pressure of migration arising from the south. Since the European Union itself is not capable of this, NATO must also play a role in the undertaking of this task. The military alliance, with the mission to complete service in the Aegean and Mediterranean seas, as well as with the intelligence data, is helping public efforts facing human traffickers.

Frontex, the European Border and Coast Guard Agency, promotes, coordinates and develops European border management in line with the EU fundamental rights charter and the concept of Integrated Border Management.

On December 14, 2017, the Visegrád Four decided that they are going to give considerable financial contributions and will undertake assistance in the interest of helping Italy defend its sea borders. The contribution helps efforts throughout the European Union Libyan territories with great support and with this they ensure the total financing of the second phase of the Libyan border defence strengthening program, as well as offer collaboration in the execution of this.

In March of 2018, Hungary arranged the meeting for the Ministers of the V4 and Central European Defense Cooperation, where the party members realized, that the safety of the regions are the key to Europe's future. Safety can then become even more robust if we collaborate more closely and efficiently in the region and we develop our abilities further, for which one of the tools is the plans of public action, and the community's larger and more efficient presence in the crisis belt.

From the perspective of safety issue, it is necessary to note that the Hungarian Government is stressing further that, according to its stance, the problem needs to be remedied where it develops. Therefore, it is necessary to assess the catalyst reasons for immigration in order to act against them as opportunity allows in those countries where they start. Inspired by this, the Assistant Secretary of Anti-Christian Persecution was created in 2016, which, for example, builds community houses in Iraq, Syria, and Lebanon with the help of the Ecumenical Humanitarian Aid Agency. Furthermore, special scholarship programs were created for the benefit of youths in persecuted 
Christian families, as well as working with the assistance from Pázmány Péter Catholic University on the creation of Hungarian founded universities. In addition to all this, it supports with more than 400 million forints the re-building of 4 schools and a hospital in the Nigerian Maiduguri Catholic Church County.

The things mentioned above are very thought provoking because the writings which assess national security, in many instances, deal with and contain information almost exclusively about the safety of countries and/or regions that are affected by migration. The safety of the refugees is almost never focused upon. This proposal is interesting, in that it references risks that put human societies in danger - not in the issue of national security, but rather in the matter of human security. In doing so, the investigation would not be in the center of risk protection or the safety of countries surrounded by state borders, but rather in the center of the society creating man. I honestly believe that the main task of non-governmental organizations in the course of immigration management is the observation of these human fates and the respective assistance of them.

\section{Conclusion}

The creation and/or upkeep of safety is a public duty, on which civil and law enforcement, national and international agencies need to take action, working together as a group. The national civil example of the remedying of safety issues is the 50 -some border guards recruited into the Police Reserves troops, who started their patrol services in the summer of 2017. The National Civil Watch Alliance works in a civil organization form, which monitors the present migrants and helps by immediately signalling the authorities in joint service with the Police Department in deeper border regions. The further continuation of this initiative is the creation of the Department of Civil Border Protection.

The Police Department works closely with the national security services in the carrying out of assignments and tasks related to immigration.

The public actions of the Police Department and the Military Forces justified the broadening of their extra assignments and of their powers through their exemplary service, which extended across the border.

International institution collaboration in our country is the Public Liaison Service Locations, operating in more than 10 settlements along the border. Foreign and local soldiers and police are completing service within and outside of our borders equally with personal national cooperation. Among organizational fields, the highlighting of the NATO-EU, PESCO, V4, Central European Defense Cooperation form is justified while answering the security questions related to immigration.

The significant players in the management of the issue strongly emphasize that the management of problems arising from immigration must be remedied in their place of origin. This view confirms for me the importance of non-governmental organizations 
taking a role in the immigration issue, according to which it is necessary to concentrate on human safety.

\section{REFERENCES}

Balla József (2017): A Magyar Honvédség helye és szerepe a határơrizeti rendszerben. Hadtudományi Szemle, Vol. 10, No. 1. 354-364.

Bódi Stefánia (2015): Jogszabályváltozások a tömeges bevándorlás okozta válsághelyzetben, különös tekintettel a Magyar Honvédség és a rendőrség többletfeladataira. Jogelméleti Szemle, No. 4. 88-101.

Christián László (2017): „Rendőri helyzetjelentés a frontvonalról”. A 2015. évi migrációs helyzet rendőri kezelése. In Tálas Péter ed.: Magyarország és a 2015-ös migrációs válság. 149-157.

Csiki Tamás - Német Bence - Tálas Péter (2012): A többnemzeti katonai képességfejlesztésről a Közép-európai Védelmi Együttműködési Kerekasztal kapcsán. Nemzet és Biztonság, Nos. 5-6. 124-132.

Kovács Gábor: A Magyar Rendőrség szerepvállalása hazánk határbiztonságában és a schengeni külső határok ellenőrzésében. Available: http://www.pecshor.hu/periodika/XVI/kovacs.pdf, (Downloaded: 25.06.2018.)

Laufer Balázs (2017): Migrációs státuszkérelmezők esetében felmerülő lehetséges nemzetbiztonsági és terror kockázatok. Terror \& Elhárítás, No. 3. 67-107. Available: http://epa.oszk. hu/02900/02932/00012/pdf/EPA02932_terror_elharitas_2017_3_067-107.pdf (Downloaded: 30.06.2018.)

Papp Csaba Lajos (2011): A magyar-román államhatáron átnyúló rendészeti együttmüködés kialakitása és müködtetése. Available: http://193.224.76.2/downloads/konyvtar/digitgy/phd/2012/papp_ csaba_lajos_thu.pdf (Downloaded: 25.06.2018.)

Ritecz György: Az irreguláris migráció kezelés fejlődése(?), fejlődés-e? Available: http://www.pecshor.hu/ periodika/XIX/ritecz.pdf (Downloaded: 27.06.2018.)

Szabó László András (2017): A migráció hatása a közigazgatásra. Magyar Rendészet, No. 1. 159-174.

Szenes Zoltán (2016): Biztonságpolitika és válságkezelés. A migráció és biztonság összefüggései. 32-41. Available: http://m.ludita.uni-nke.hu/repozitorium/bitstream/handle/11410/10138/Biztonsagpolitika_valsagkezeles.pdf?sequence=18isAllowed=y, (Downloaded: 25.06.2018.)

Varga János (2015): A nemzetközi együttmüködés lehetőségei az illegális migráció rendőrségi kezelésében. In Hautzinger Zoltán ed.: Migráció és rendészet. 231-241. Available: http://real.mtak. hu/41091/1/Migracio_Rendeszet_u.pdf (Downloaded: 06.30.2018.)

\section{Internet Sources}

http://www.bmbah.hu/index.php?option=com_k2\&view=item\&layout=item\&id=177\&Item$\mathrm{id}=12328 \mathrm{lang}=\mathrm{hu}$ (Downloaded: 15.05.2017.)

http://www.consilium.europa.eu/hu/press/press-releases/2017/12/11/defence-cooperation-pesco-25-member-states-participating/ (Downloaded: 10.04.2018.)

http://www.consilium.europa.eu/hu/press/press-releases/2018/03/06/defence-cooperation-council-adopts-an-implementation-roadmap-for-the-permanent-structured-cooperation-pesco/ (Downloaded: 10.04.2018.)

http://www.consilium.europa.eu/hu/policies/defence-security/ (Downloaded: 10.04.2018.)

http://www.hirado.hu/2017/02/28/civil-szervezetek-finanszirozasat-vizsgaljak-olaszorszagban/

(Downloaded: 24.05.2017.)

https://frontex.europa.eu/ (Downloaded: 25.06.2018.) 
https://honvedelem.hu (Downloaded: 25.06.2018.)

http://hvg.hu/itthon/20170314_A_Strasbourgi_Birosag_iteltete_lenullazhatja_a_kormany_menekultugyi_terveit (Downloaded: 24.05.2017.)

http://inforadio.hu/belfold/2017/03/02/lazar_szeptemberig_ervenyben_marad_a_tomeges_bevandorlas_okozta_valsaghelyzet/ (Downloaded: 15.05.2017.)

http://www.karpataljalap.net/?q=2017/01/02/mukodik-kozos-kapcsolattartasi-szolgalati-hely-zahonynal (Downloaded: 15.05.2017.)

http://kitekinto.hu/2017/04/06/europai-ugyek/pentektol-szigorubb-a-hatarellenorzesi-szabalyozas-az-eu-ban/ (Downloaded: 16.05.2017.)

http://www.kormany.hu (Downloaded: 16.05.2017.)

http://www.opsz.hu/storage/upload/dokumentumok//intezkedesiterv_hatarszakaszra.pdf (Downloaded: 17.09.2016.)

http://www.opsz.hu/kozponti/zaszlot-bontott-a-hatarvedelmi-tagozat (Downloaded: 24.05.2017.)

http://www.police.hu/hu/a-rendorsegrol/testulet/altalanosan/a-rendorseg-szervezete (Downloaded: 10.04.2018.)

Napi kommunikáció, MK napi üzenetek, online hírlevél, napikommunikacio@lists.fidesz.hu

\section{Laws:}

https://uj.jogtar.hu/login

91/2005. (V. 6.) Korm. rendelet

2007. évi LXXX. törvény a menedékjogról

274/2007. (X. 20.) Korm. rendelet a Magyar Köztársaság Kormánya és az Osztrák Szövetségi Kormány között Hegyeshalom-Nickelsdorfban közös kapcsolattartási szolgálati helyen történő együttmüködésről szóló Megállapodás kihirdetéséről

329/2007. (XII. 13.) Korm. rendelet a Rendőrség szerveiről és a Rendőrség szerveinek feladat- és hatásköréről

Magyarország Alaptörvénye (2011. április 25.)

2011. évi CXIII. törvény a honvédelemről és a Magyar Honvédségről, valamint a különleges jogrendben bevezethető intézkedésekről

30/2011. (IX. 22.) BM rendelet a rendőrség szolgálati szabályzatáról

A belügyminiszter és a honvédelmi miniszter 25/2015. (IX. 14.) BM-HM együttes utasítása a Magyar Honvédségnek a rendőrségi feladatok ellátásában történő közremüködése rendjéről 